\title{
Pengaruh Tempe Dedak dan Tape Dedak terhadap Karakteristik Organoleptik Daging Broiler
}

\author{
Siti Kurniati ${ }^{1}$, Urip Santoso ${ }^{1 *}$ dan Yosi Fenita ${ }^{1}$ \\ ${ }^{1}$ Jurusan Peternakan, Fakultas Pertanian, Universitas Bengkulu Jalan W.R. Supratman, Kandang Limun, Bengkulu, \\ 38371. \\ *Penulis korespondensi: santoso@unib.ac.id
}

Artikel ini diterima (received): 19 Mei 2020; dinyatakan disetujui (accepted): 25 November 2020; terbit (published): 27 November 2020. Artikel ini dipublikasi secara daring pada https://ejournal.unib.ac.id/index.php/buletin pt/index

\begin{abstract}
Abstrak
Penelitian ini bertujuan untuk mengevaluasi pengaruh tempe dedak dan tape dedak terhadap karakteristik organoleptik daging broiler. Penelitian ini menggunakan rancangan acak lengkap dengan 5 perlakuan sebagai berikut, $\mathrm{PO}=$ Ransum kontrol, tidak mengandung tempe dedak dan tape dedak, $\mathrm{P} 1=$ Ransum mengandung $14 \%$ tempe dedak, $\mathrm{P} 2=$ Ransum mengandung $20 \%$ tempe dedak, $\mathrm{P} 3=$ Ransum mengandung $14 \%$ tape dedak, dan $\mathrm{P} 4=$ Ransum mengandung $20 \%$ tape dedak. Hasil penelitian menunjukkan warna daging lebih tinggi pada P1, P2, P3 dan P4 dibandingkan dengan P0. P2 dan P4 mempunyai bau amis daging yang paling rendah, dan mempunyai rasa daging yang lebih enak serta tekstur daging yang lebih lembut. Dapat disimpulkan bahwa pemberian tempe dedak dan tape dedak dalam ransum meningkatkan karakteristik organoleptik daging broiler.
\end{abstract}

Kata kunci: Tempe Dedak, Tape Dedak, Karakteristik Organoleptik, Daging Broiler.

\section{Pendahuluan}

Pakan unggas masih didominasi oleh jagung yaitu sebanyak 50-60\%, padahal jagung mempunyai harga yang mahal dikarenakan jagung juga dikonsumsi oleh manusia. Sebagian jagung dapat digantikan oleh dedak padi yang mempunyai harga yang murah. Penggunaan dedak padi pada pakan broiler masih sangat rendah yaitu sekitar 5\%, dikarenakan kadar serat kasar (Santoso et al., 2015) dan asam fitat yang tinggi (Fitriyani et al., 2019; Fatimah et al., 2020).

Salah satu cara untuk menurunkan serat kasar dan asam fitat dedak pada adalah dengan biofermentasi. Fermentasi oleh mikroba mampu mengubah makro molekul protein menjadi mikro molekul yang mudah dicerna oleh unggas dan tidak menghasilkan senyawa beracun (Pamungkas, 2011). Dilaporkan juga bahwa selain dapat meningkatkan kandungan protein dalam ransum, proses fermentasi juga dapat meningkatkan kecernaan pakan dan dapat melepas ikatan senyawa kompleks menjadi senyawa yang mudah dicerna (Santoso, 2014).

Dedak padi dapat difermentasi dengan ragi tempe (produknya disebut tempe dedak) dan ragi tape (produknya disebut tape dedak). Dedak yang difermentasi dengan Rhizopus oligosporus meningkatkan protein dan menurunkan asam fitat sehingga ketersediaan mineral seperti Fe meningkat. Protein dan Fe merupakan senyawa yang berperan dalam sintesis hemoglobin dan mioglobin daging (Suhenda et al., A., 2010) sehingga diduga pemberian tempe dedak meningkatkan warna daging. Hasil penelitian Ratnasari (2017) bahwa tempe dedak dapat diberi sebanyak $14 \%$ dengan menghasilkan warna daging lebih merah, rasa yang lebih enak dan bau amis yang lebih rendah. Terdapat kecenderungan bahwa pemberian tempe dedak yang lebih tinggi akan 
menghasilkan karakteristik organoleptik daging yang lebih baik. Oleh sebab itu, diduga pemberian tempe dedak dapat ditingkatkan.

Tape dedak merupakan produk yang didapatkan dari proses fermentasi dedak padi dengan menggunakan ragi tape Ragi tape sebagai inokulan fermentasi nyata dapat meningkatkan kandungan protein dedak (Wibawa et al., 2015) dan sebaliknya nyata menurunkan kandungan serat kasar pakan (Pamungkas, 2011). Tape dedak mempunyai kadar protein yang lebih tinggi jika dibandingkan dengan dedak (Fatimah et al., 2020). Pengaruh pemberian tape dedak terhadap karakteristik organoleptik daging broiler belum diteliti. Berdasarkan uraian di atas, maka penelitian ini bertujuan untuk mengevaluasi pengaruh pemberian tempe dedak dan tape dedak dalam ransum terhadap karakteristik organoleptik daging broiler. mengurangi karakteristik organoleptik daging broiler.

\section{Bahan dan Metode}

Penelitian ini dilaksanakan pada bulan 24 April - 28 Mei 2019 di Laboratorium Peternakan, Jurusan Peternakan, Fakultas Pertanian, Universitas Bengkulu.

\section{Pembuatan Tempe Dedak dan Tape Dedak}

Pembuatan tempe dedak dilakukan dengan cara mencampur dedak dan air dengan perbandingan $1: 1$. Setelah itu dedak dikukus selama 30 menit agar dedak menjadi lebih lunak dan kontaminan yang lebih rendah. Selanjutnya, dedak didinginkan dan diberi ragi tempe sebanyak $4 \mathrm{~g} / \mathrm{kg}$ dedak. Dedak selanjutnya dibungkus dengan plastik erlubang. Fermentasi dilakukan selama 72 jam. Tempe dedak yang sudah jadi dijemur sampai kering, digiling dan disimpan dalam kantong plastik sebelum digunakan.

Pembuatan tempe dedak dilakukan dengan cara mencampur dedak dan air dengan perbandingan $1: 1$. Setelah itu dedak dikukus selama 30 menit agar dedak menjadi lebih lunak dan kontaminan yang lebih rendah. Selanjutnya, dedak didinginkan dan diberi ragi tape sebanyak $5 \mathrm{~g} / \mathrm{kg}$ dedak (Santoso et al., 2015). Dedak selanjutnya dibungkus dengan plastik tanpa lubang. Fermentasi dilakukan selama 48 jam. Tape dedak yang sudah jadi dijemur sampai kering, digiling dan disimpan dalam kantong plastik sebelum digunakan.

\section{Kandang, Ternak dan Pakan}

Kandang, petak kandang dan peralatannya dibersihkan dan didesinfektan terlebih dahulu sebelum digunakan. Petak kandang penelitian yang beralaskan sekam padi dengan ketebalan $5 \mathrm{~cm}$ berukuran $1 \times 1 \times 0,65 \mathrm{~m}$.

Penelitian ini menggunakan dengan jumlah 120 ekor broiler umur 21 hari dan didistribusikan ke dalam petak-petak percobaan lalu diberikan pakan percobaan selama 21 hari. Penelitian ini menggunakan rancangan acak lengkap dengan 5 perlakuan, 4 ulangan dengan setiap ulangan berisi 6 ekor sebagai berikut, $\mathrm{PO}=$ Ransum kontrol, tidak mengandung tempe dedak dan tape dedak, $\mathrm{P} 1=$ Ransum mengandung $14 \%$ tempe dedak, $\mathrm{P} 2=$ Ransum mengandung $20 \%$ tempe dedak, P3= Ransum mengandung 14\% tape dedak, dan P4= Ransum mengandung 20\% tape dedak. Susunan pakan penelitian disajikan pada Tabel 1.

Variabel yang diukur yaitu warna daging (Gambar 1), bau daging, rasa daging dan tekstur daging. Pengukuran variabel di atas dilakukan menurut metode Santoso et al. (2002).

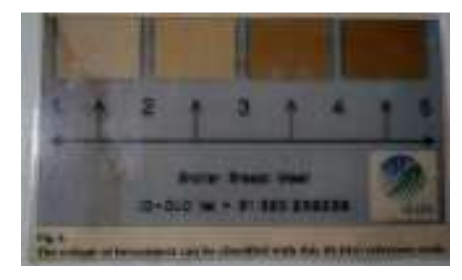

Gambar 1. Warna standar ID-DL0

\section{Analisis Data}

Data dianalisis menggunakan metode deskriptif dengan menggunakan modus pada setiap variabel (uji bau daging, uji rasa daging, dan uji tekstur daging), sementara warna daging dianalisis berdasarkan rataan. 
Tabel 1. Susunan pakan penelitian

\begin{tabular}{|c|c|c|c|c|c|}
\hline Bahan Pakan \% & $\mathrm{P} 0(\%)$ & $\mathrm{P} 1(\%)$ & $\mathrm{P} 2(\%)$ & P3(\%) & $\mathrm{P} 4(\%)$ \\
\hline Jagung & 57 & 48 & 42 & 48 & 42 \\
\hline Konsentrat & 34,2 & 34,2 & 34,2 & 34,2 & 34,2 \\
\hline Dedak & 5 & 0 & 0 & 0 & 0 \\
\hline Tempe dedak & 0 & 14 & 20 & 0 & 0 \\
\hline Tape dedak & 0 & 0 & 0 & 14 & 20 \\
\hline Mineral mix & 1,7 & 1,7 & 1,7 & 1,7 & 1,7 \\
\hline Top mix & 0,5 & 0,5 & 0,5 & 0,5 & 0,5 \\
\hline Garam & 0,1 & 0,1 & 0,1 & 0,1 & 0,1 \\
\hline Minyak & 1,5 & 1,5 & 1,5 & 1,5 & 1,5 \\
\hline Total & 100 & 100 & 100 & 100 & 100 \\
\hline
\end{tabular}

Kandungan Nutrisi

\begin{tabular}{lccccc}
\hline Protein Kasar (\%) & 19,76 & 19,99 & 20,11 & 20,47 & 20,79 \\
ME (kkal) & 2940 & 2828 & 2747 & 2854 & 2784 \\
Ca (\%) & 1,50 & 1,56 & 1,59 & 1,54 & 1,56 \\
P (\%) & 0,85 & 0,89 & 0,93 & 0,90 & $0,0,94$
\end{tabular}

Keterangan: $\mathrm{P} 0=$ kontrol, $\mathrm{P} 1=$ pemberian $14 \%$ tempe dedak , $\mathrm{P} 2=$ pemberian $20 \%$ tempe dedak, $\mathrm{P} 3=$ pemberian $14 \%$ tape dedak ,P4 = pemberian $20 \%$ tape dedak.

\section{Hasil dan Pembahasan}

\section{Pengaruh Pelakuan terhadap Warna Daging}

Pengaruh pemberian tempe dedak dan tape dedak terhadap warna daging berdasarkan nilai rataan pada setiap perlakuan pada Tabel 2 .

Hasil penelitian menunjukkan bahwa rataan skor warna daging broiler pada P1, P2, P3, dan P4 lebih tinggi bila dibandingkan dengan kontrol (P0) masing - masing sebesar $20 \%, 20 \%$, $26,67 \%$ dan $33,33 \%$. Hasil analisis proksimat (Fatimah et al., 2020) menujukkan bahwa fermentasi meningkatkan kadar protein dan menurunkan kadar asam fitat dedak. Penurunan asam fitat akan meningkatkan ketersediaan mineral termasuk besi dan ketersediaan protein.
Zat besi dan protein sangat diperlukan dalam sintesis mioglobin, pigmen daging ayam (Santoso, 2014; Suhenda et al., 2010). Kosentrasi mioglobin yang lebih tinggi menyebabkan otot menjadi lebih merah. Soeparno (2015) menjelaskan bahwa warna daging dipengaruhi oleh pigmen daging yang terdiri atas dua macam protein yaitu hemoglobin dan mioglobin. Semakin tinggi kandungan protein di dalam pakan maka akan memberikan warna daging yang semakin baik.

Tape dedak juga mengandung protein lebih tinggi dan kadar asam fitat yang lebih rendah (Fatimah et al., 2020), sehingga ketersediaan protein dan mineral yang lebih tinggi (Widiyazid et al., 2002) diduga akan meningkatkan sintesis mioglobin, yang akhirnya meningkatkan warna daging. 
Table 2. Pengaruh pemberian tempe dedak dan tape dedak terhadap warna daging.

\begin{tabular}{|c|c|c|c|c|c|c|c|}
\hline \multirow{2}{*}{ Perlakuan } & \multicolumn{4}{|c|}{ Ulangan } & \multirow{2}{*}{ Rataan } & \multirow{2}{*}{ SD } & \multirow{2}{*}{ Peningkatan } \\
\hline & 1 & 2 & 3 & 4 & & & \\
\hline PO & 1,2 & 1,5 & 2 & 1,3 & 1,5 & 0,77 & \\
\hline P 1 & 1 & 1,5 & 2,5 & 2 & 1,8 & 0,84 & $20 \%$ \\
\hline $\mathrm{P} 2$ & 1,5 & 1,5 & 2 & 2 & 1,8 & 0,86 & $20 \%$ \\
\hline P3 & 2 & 1,5 & 1,5 & 2,5 & 1,9 & 0,85 & $26,67 \%$ \\
\hline P4 & 2,5 & 1,5 & 1,5 & 2,5 & 2,0 & 0,74 & $33,33 \%$ \\
\hline
\end{tabular}

$\mathrm{PO}=$ kontrol, $\mathrm{P} 1=14 \%$ tempe dedak, $\mathrm{P} 2=20 \%$ tempe dedak, $\mathrm{P} 3=14 \%$ tape dedak, $\mathrm{P} 4=$ $20 \%$ tape dedak (Rataan \pm SD)

Table 3. Pengaruh pemberian tempe dedak dan tape dedak terhadap bau daging.

\begin{tabular}{cccccc}
\hline \multirow{2}{*}{$\begin{array}{c}\text { Perlakuan } \\
\text { Skor Nilai }\end{array}$} & PO & P1 & P2 & P3 & P4 \\
\cline { 2 - 6 } & 5,0 & 0,00 & 3,75 & 7,5 & 0,00 \\
2 & 21,25 & 26,25 & 8,75 & 18,75 & 13,75 \\
3 & 28,75 & 31,25 & 26,25 & 28,75 & 30,0 \\
4 & 27,5 & 28,75 & 22,5 & 27,5 & 42,5 \\
5 & 17,5 & 13,75 & 38,75 & 17,5 & 13,75 \\
Total & 100 & 100 & 100 & 100 & 100
\end{tabular}

$\overline{\mathrm{PO}}=$ kontrol, $\mathrm{P} 1=14 \%$ tempe dedak, $\mathrm{P} 2=20 \%$ tempe dedak, $\mathrm{P} 3=14 \%$ tape dedak, $\mathrm{P} 4=$ $20 \%$ tape dedak.

Pemberian tape dedak menghasilkan daging broiler yang lebih merah jika dibandingkan dengan tempe dedak. Hal ini menunjukkan bahwa tape dedak lebih efektif dalam meningkatkan warna daging. Hasil analisis proksimat tape dedak mempunyai kadar protein dan asam fitat yang lebih rendah jika dibandingkan dengan tempe dedak (Fatimah et al., 2020). Lebih rendahnya asam fitat pada tape dedak jika dibandingkan dengan tempe dedak menunjukkan ketersediaan mineral terutama zat besi lebih tinggi. Meskipun tape dedak mengandung protein yang lebih rendah, kecernaan proteinnya diduga lebih tinggi. Hal ini diduga mengakibatkan sintesis mioglobin dan/atau hemoglobin lebih tinggi.

Sangat menarik pada hasil penelitian ini bahwa pemberian tape dedak yang lebih tinggi (14\% vs $20 \%$ ) menghasilkan warna daging yang lebih merah, sementara tempe dedak tidak. Dapat disimpulkan bahwa tape dedak menghasilkan warna daging yang lebih merah daripada tempe dedak.

\section{Pengaruh Pelakuan terhadap Bau Daging}

Pengaruh pemberian tempe dedak dan tape dedak terhadap bau daging dapat dilihat pada Tabel 3.

Angka yang semakin tinggi pada nilai uji bau daging menunjukkan bahwa bau amis semakin menurun. Dari data tersebut didapatkan bahwa pada PO panelis paling banyak memilih skor nilai 3 (bau agak amis) sebanyak 28,75\%; P1 panelis paling banyak memilih skor nilai 3 (bau agak amis) sebanyak 31,25\%; P2 panelis paling banyak memilih skor nilai 5 (bau tdak amis) sebanyak 38,75\%; P3 panelis paling banyak memilih skor nilai 3 (bau agak amis) sebanyak $28,75 \%$ dan; P4 panelis paling banyak memilih skor nilai 4 (bau sedikit amis) sebanyak $42,5 \%$. Jadi, P2 dan P4 mempunyai bau amis yang lebih rendah daripada PO. Data yang menarik lainnya adalah bahwa P2 mempunyai bau amis yang lebih rendah daripada P4. 
Table 4. Pengaruh pemberian tempe dedak dan tape dedak terhadap rasa daging.

\begin{tabular}{cccccc}
\hline \multirow{2}{*}{$\begin{array}{c}\text { Perlakuan } \\
\text { Skor Nilai }\end{array}$} & P0 & P1 & P2 & P3 & P4 \\
\cline { 2 - 6 } 1 & 3,75 & 7,5 & 6,25 & 15,0 & 0,00 \\
2 & 17,5 & 20,0 & 21,25 & 13,75 & 17,5 \\
3 & 52,5 & 37,5 & 35,0 & 33,75 & 51,25 \\
4 & 25,0 & 32,5 & 37,5 & 35,0 & 30,0 \\
5 & 1,25 & 2,5 & 0,00 & 2,5 & 1,25 \\
Total & 100 & 100 & 100 & 100 & 100
\end{tabular}

$\mathrm{P} 0=$ kontrol, $\mathrm{P} 1=14 \%$ tempe dedak, $\mathrm{P} 2=20 \%$ tempe dedak, $\mathrm{P} 3=14 \%$ tape dedak, $\mathrm{P} 4=$ $20 \%$ tape dedak.

Menurut Suliantari dan Rahayu (1990) bahwa fermentasi menghilangkan senyawa beracun, menghilangkan bau pada makanan mentah, dan menambah flavour (rasa). Dedak yang difermentasi mengandung kadar fenolik total yang lebih tinggi jika dibandingkan dengan dedak yang tidak terfermentasi. Dedak yang difermentasi dengan Rhizopus oligosporus meningkatkan total fenolik (Aruben, 2011). Senyawa fenolik merupakan senyawa antioksidan sehingga akan menurunkan oksidasi asam lemak tak jenuh dalam daging. Menurunnya oksidasi asam lemak ini merupakan salah satu faktor menurunnya bau amis daging. Selain itu, bau daging dipengaruhi oleh perubahan ATP menjadi hipoksantin. Semakin tinggi ATP yang diubah menjadi hipoksatin maka semakin tinggi pula bau daging (Santoso, 2014).

Oboh et al. (2012) melaporkan bahwa fermentasi dengan Saccharomyces cerevisae meningkatkan kadar fenol dan aktivitas antioksidan. Jadi, diduga tape dedak juga mengandung kadar fenol yang lebih tinggi yang dapat meningkatkan aktivitas antioksidan sehingga akan mengurangi oksidasi asam lemak tak jenuh. Hal ini yang merupakan salah satu faktor yang menurunkan bau amis daging pada P4.

Dari hasil penelitian ini terlihat bahwa level pemberian sangat berperan dalam upaya menurunkan bau amis. Baik tempe dedak maupun tape dedak mampu menurunkan bau amis daging jika diberikan sebanyak $20 \%$. Selain itu, tempe dedak lebih efektif dalam menurunkan bau amis daging. Diperlukan penelitian lebih lanjut tentang perbandingan kadar fenol dan aktivitas antioksidan antara tempe dedak dan tape dedak.

\section{Pengaruh Perlakuan terhadap Rasa Daging}

Pengaruh pemberian tempe dedak dan tape dedak terhadap rasa daging dapat dilihat pada Tabel4

Angka yang tinggi pada nilai uji rasa daging menujukkan bahwa rasa semakin enak. Dari data tersebut didapatkan bahwa pada PO panelis paling banyak memilih skor nilai 3 (rasa cukup enak) sebanyak 52,5\%; P1 panelis paling banyak memilih skor nilai 3 (rasa cukup enak) sebanyak 37,5\%; P2 panelis paling banyak memilih skor nilai 4 (rasa enak) sebanyak 37,5\%; P3 panelis paling banyak memilih skor nilai 4 (rasa enak) sebanyak 35,0\% dan; P4 panelis paling banyak memilih skor nilai 3 (rasa cukup enak) sebanyak 51,25\%. Jadi, P2 dan P3 mempunyai rasa daging yang lebih tinggi.

Senyawa aktif utama rasa daging ayam adalah asam glutamat, ion kalium dan IMP. Penurunan asam fitat pada tempe dedak dan tape dedak akan meningkatkan ketersediaan mineral, sementara Santoso et al. (2015) melaporkan bahwa fermentasi meningkatkan asam glutamat pada bahan pakan. Diduga proses fermentasi pada dedak oleh ragi tempe (tempe dedak) atau ragi tape (tape dedak) 
Table 5. Pengaruh pemberian tempe dedak dan tape dedak terhadap tekstur daging.

\begin{tabular}{cccccc}
\hline \multirow{2}{*}{$\begin{array}{c}\text { Perlakuan } \\
\text { Skor Nilai }\end{array}$} & P0 & P1 & P2 & P3 & P4 \\
\cline { 2 - 6 } & & \multicolumn{5}{c}{$\%$} & \\
\hline 1 & 10,0 & 2,5 & 2,5 & 1,25 & 0,00 \\
2 & 15,0 & 20,0 & 21,25 & 6,25 & 13,75 \\
3 & 30,0 & 36,25 & 32,5 & 43,75 & 30,0 \\
5 & 37,5 & 30,0 & 35,0 & 40,0 & 42,5 \\
Total & 7,5 & 11,25 & 8,75 & 8,75 & 13,75 \\
& 100 & 100 & 100 & 100 & 100
\end{tabular}

\footnotetext{
$\mathrm{PO}=$ kontrol, $\mathrm{P} 1=14 \%$ tempe dedak, $\mathrm{P} 2=20 \%$ tempe dedak, $\mathrm{P} 3=14 \%$ tape dedak, $\mathrm{P} 4=$ $20 \%$ tape dedak.
}

meningkatkan asam glutamat dan kalium. Perubahan ATP menjadi IMP sangat menentukan rasa daging (Santoso et al., 2010; Santoso, 2014). Sangat menarik untuk meneliti perubahan ATP menjadi IMP pada tempe dedak dan tape dedak.

\section{Pengaruh Perlakuan terhadap Tekstur Daging}

Pengaruh pemberian tempe dedak dan tape dedak terhadap tekstur daging dapat dilihat pada Tabel5

Angka yang tinggi pada nilai uji tekstur daging menujukkan bahwa rasa semakin empuk. Dari data tersebut didapatkan bahwa pada PO panelis paling banyak memilih skor nilai 4 (tekstur empuk) sebanyak 37,5\%; P1 panelis paling banyak memilih skor nilai 3 (tekstur cukup empuk) sebanyak 36,25\%; P2 panelis paling banyak memilih skor nilai 4 (tekstur empuk) sebanyak 35,0\%; P3 panelis paling banyak memilih skor nilai 3 (rasa cukup empuk) sebanyak 43,75\% dan; P4 panelis paling banyak memilih skor nilai 4 (tekstur empuk) sebanyak 42,5\%. Jadi, P1 dan P3 mempunyai tekstur daging yang lebih keras daripada perlakuan yang lain. Jadi pemberian tempe dedak atau tape dedak sebanyak $14 \%$ menurunkan keempukkan daging broiler. Semakin tinggi lemak marbling membuat daging semakin empuk (Soeparno, 2015). Luas dan jumlah lemak intramuskular (marbling) juga akan membuat daging lebih empuk, karena lemak lebih lembut dibandingkan otot.

\section{Kesimpulan}

Berdasarkan hasil penelitian dapat disimpulkan bahwa tempe dedak atau tape dedak dalam ransum dapat diberikan sampai dengan $20 \%$ dengan menghasilkan karakteristik organoleptik yang lebih tinggi.

\section{Daftar Pustaka}

Aruben, W. N. 2011. Peningkatan kosentrasi senyawa fenolik antioksidan dari dedak dengan cara fermentasi. Jurusan Teknik Kimia. Fakultas Teknik. UNDIP. Semarang.

Fatimah, S. U. Santoso dan Y. Fenita. 2020. Pengaruh penggunaan tempe dedak dan tape dedak terhadap performa ayam broiler. Jurnal Sain Peternakan Indonesia (in press).

Fitriyani, I. N., U. Santoso dan T. Akbarillah. 2019. Pengaruh pemberian tempe dedak terhadap performa ayam broiler. Jurnal Sain Peternakan Indonesia, 14 (3): 246-251.

Oboh, G., A. O. Ademosun dan L. Lajide. 2012. Improvement of the nutritive value and antioxidant properties of citrus peels through Saccaromyces cerevisae solid substrate fermentation for utilization in livestock feed. Volume 24, Article \#9. Retrieved May 19, 2020, from http://www.Irrd.org/Irrd24/1/oboh24009.h tm. 
Pamungkas, W. 2011. Teknologi fermentasi, alternatif solusi dalam pemanfaatan bahan pakan lokal. Media Akuakultur 6 (1): 43-48.

Ratnasari, D. 2017. Pengaruh pemberian tempe dedak terhadap uji organoleptik pada daging broiler. Skripsi Fakultas Pertanian Universitas Bengkulu. Bengkulu.

Santoso, U., T.Suteky, Heryanto dan Sunarti. 2002. Effects of Sauropus Androgynus (Katuk) leaf extract on growth, fataccumulation and fecal microorganisms in broiler chickens. Jurnal Ilmu Ternak dan Veteriner, 6:220-226.

Santoso, U., Kususiyah dan Y. Fenita. 2010. The effect of Sauropus Androgynus extract and lemuru oil on fat deposition and fatty acid composition of meat in broiler chickens. J.Indonesia Trop.Anim.Agric. 35(1): 48-54.

Santoso, U. (2014). Katuk, Tumbuhan Multikhasiat. BPFP, Unib, Bengkulu.

Santoso, U., Y. Fenita dan Kususiyah. 2015. Effect of Fermented Sauropus Androgynus Leavs Meat Compsition, amino acid and fatty acid composition in broiler chickens. Pak. J. Nurt. 14: 799-807.
Soeparno. 2015. Ilmu dan Teknologi Daging. Edisi kedua. Gajah Mada University Press, Yogyakarta.

Suhenda, N., R. Samsudin dan I. Melati. 2010. Peningkatan kualitas bahan nabati (dedak padidan dedak pola) melalui proses fermentasi (Rhizopus oligosporus) dan penggunaannya dalam pakan ikan (Cyprinus carpio). Prosiding Forum Inovasi Teknologi Akuakultur.

Sulianturi dan W. P. Rahayu. 1990. Teknologi Fermentasi Umbi-umbian dan Biji-bijian. Bahan Pengajar Pusat Antar Universitas Pangan dan Gizi, Institusi Pertanian Bogor. $152 \mathrm{HIm}$. Bogor.

Wibawa, A. A. P., I. W. Wiryawan dan I. B. G. Partama. 2015. Peningkatan nutrisi dedak padi sebagai pakan itik melalui biofermentasi dengan khamir. Majalah Ilmiah Peternakan, 18 (1): 11-16.

Widiyazid, S. I. K., Parwati I. A., Suyasa N., Guntoro S., Londra I. M., Triagastia I. K., Adnyana Putra A.A.G., dan Widianta G.M. 2002. Laporan Akhir Kajian Sistem Usaha Pertanian Sapi Potong Berbasis Ekoregional Lahan Kering. Instalasi Penelitian dan Pengkajian Teknologi Pertanian, Denpasar 